\title{
Production Globalization or Localization?
}

\author{
Shun Xiao \\ College of Economics, Jinan University, Guangzhou, China \\ Email: xiaoshun2011@126.com
}

How to cite this paper: Xiao, S. (2018) Production Globalization or Localization? Modern Economy, 9, 572-585. https://doi.org/10.4236/me.2018.93037

Received: March 5, 2018

Accepted: March 25, 2018

Published: March 28, 2018

Copyright $\odot 2018$ by author and Scientific Research Publishing Inc. This work is licensed under the Creative Commons Attribution International License (CC BY 4.0).

http://creativecommons.org/licenses/by/4.0/

(c) (i) Open Access

\begin{abstract}
As the global production expanding, vertical specialization is thinner and thinner; most countries are just one "node" of product value chain, and the trade of intermediate products is the goods transferring from one node to another. We may wonder whether there is a law in the connections between the "nodes", whether the connections are subject to political system, religious culture or geographic distance. This paper adopts a new accounting systemvalue added accounting system-to measure the trade flows between countries, and the ratio of value added export (VAX ratio) is used to measure the degree of processing trade. Setting 60 major economies trading with China as samples, it turns out that processing trade tend to occur between countries closed or with regional trade agreements. With time going, the influence of distance on processing trade is becoming more and more significant, naming localization.
\end{abstract}

\section{Keywords}

Processing Trade, Trade in Value Added Accounting System, Value Added to Export Ratio

\section{Introduction}

With the continuous development of international trade, there are two forms of trade today: general trade and processing trade. Processing trade is the result of the division of international trade. In order to maximize the use of comparative advantages, the division of labor in the trade becomes more and more specialized, and the proportion of processing trade in international trade is getting higher and higher, especially in China and Mexico. Processing trade is always an important part of China's open economy. From the mid-1990s to the 2008, when international financial crisis occurred, the export of processing trade always accounted for half of China's exports. After the financial crisis, the proportion of 
processing trade declined year by year. For the first time, the share of general trade in exports surpassed that of processing trade in 2011, and the gap widened each year. In the first three quarters of 2016, the export of processing trade accounted for $33 \%$ of the total export volume, 22 percentage points lower than the general trade.

Actually, recent decades have seen the emergence of global supply chains in which production stage is sliced up and distributed across countries. We also name it global value chains, vertical specialization, fragmentation or intra-product specialization. However, many of these production activities may be more accurately described as "localization", since countries participating in the value chains are closed geographically. For example, auto parts trade is concentrated within North America, while production and assemblage of electronic components occur within Asia. On the one hand, proximity conserves on trade costs that are incurred based on the distance gross shipments travel between production stages; on the other hand, regional trade integration initiatives have lowered trade barriers preferentially among nearby countries.

\section{Literature Review}

\subsection{Influence Factors on Trade}

With the continuous development of science and technology, plus improvement of the international trading system, trade costs (transportation costs and communication costs) are reducing. It looks like that trade is no longer confined to a certain region, and the scope of trade partners will have no limits. It seems that impact of distance on trade is getting smaller and smaller. Carrere [1] uses trade volume as a weight to calculate the distance of trade (DoT) between the economies, coming to the conclusion that most countries tend to trade with countries that are closer to themselves. Wan Lunlai [2] verified that cultural distance, geographical distance, and institutional distance have a strong influence on China's import and export trade, especially the cultural distance. Ellis [3] believes that cultural distance influences trade behavior through customs, consumption concepts, and language differences. Meyer [4] believes that institutional distance will increase the cost of trade negotiations and hinder trade flows between the two countries. Yi Keimu [5] uses a multi-stage production model to explain the "prejudice" of domestic trade. When a product shifts from one stage of production to the next, the cost of transport and tariffs to be transferred abroad is much greater than that of domestic ones. If there are many stages of production, and every stage is shifted from one country to another, the trade cost will increase several times, and vertical specialization just amplify trade cost.

\subsection{Researches on Trade in Value Added Accounting System}

For the first time in the 1960s, Balassa [6] proposed vertical specialization: interconnectedness of production process in a vertical trading chain stretches across many countries, with each country specialization in particular stages of a 
good's production sequence. The first measure of vertical specialization, proposed by HIY [7], refers to the imported content in a country's exports. This measure, labeled as VS, includes both the directly and indirectly imported input content in exports. The method is based on two harsh conditions: firstly, the intensity in the use of imported is the same between production for exports and production for domestic scales; secondly, imports are 100\% foreign sourced. However, these two conditions are difficult to meet in reality.

After the 21st century, the compilation of non-competitive input-output tables in the country and the region has made great strides, thus making it possible to capture the trade links of intermediate products between different countries and industries as well as destinations. A new trade accounting system-Trade in Value Added Accounting System-began to draw attentions. Koopman et al. [8] [9] used input-output tables to decompose gross export into various components, including exports of value added, domestic value added that returns home, foreign value added, and other additional double counted terms.

Wang Zhi [10] et al. extended the export decomposition from country level to the sectoral level, further subdividing the export volume and facilitating the structural analysis of the global value chain. Johnson and Noguera [11] [12] proposed an indicator to summarize how much fragmentation has taken place, the ratio of value added to export, naming VAX ratio.

The above authors studied the value added of a country or an industry macroscopically. Ma Hong [13] proposed a new estimation strategy to estimate the domestic value-added content in China's exports by firm types.

Whether it is the traditional trade accounting system or the new trade accounting system, the focus of research on processing trade lies in the competitiveness of China's processing trade in international trade and its transformation and upgrading. Few scholars concentrate on the flow of processing trade and the factors influencing the choice of trading partner. There are two reasons: firstly, the data source is limited. At present, there are only a small amount of statistics on processing trade. Whether it is the Customs Statistical Yearbook or the Ministry of Commerce's database, the statistics on processing trade in different countries and industries are incomplete and cannot be fully studied. Secondly, even if the existing data are used for research, the results of the research are not convincing because the processing trade leads to the double counting of values and cannot reflect the real situation of the processing trade.

In the past, the literature on processing trade generally took intermediate product trade or component trade as the measure of the scale of processing trade. In this paper, the proportion of domestic value added export is taken as the standard to measure the scale of processing trade. The two kinds of measures reflect different information. If the country processes the intermediate product for final consumption by itself, the total volume of trade is equal to the value-added trade volume. If the intermediate product is processed and returned to the exporting country or re-export to third countries, the total volume of trade 
and value added of trade would be inconsistent. Trade in value added accounting system not only helps to clarify the international trade relations, but also helps to explore the trend of international division and fragmented production.

\section{Indicators and Data Sources}

\subsection{Trade in Value Added Accounting System}

Assuming there are $\mathrm{N}$ countries in the world, each country produces only one tradable product that can be consumed by both domestic and foreign consumers as the final product or used as an intermediate input (Table 1).

$x_{n 1}$ denotes the intermediate produced by country $\mathrm{n}$ but absorbed by country

$1 ; y_{n 1}$ denotes the final good produced by country $\mathrm{n}$ but absorbed by country 1 .

Horizontal view:

$$
x_{n 1}+x_{n 2}+\cdots+x_{n n}+y_{n 1}+y_{n 2}+\cdots+y_{n n}=X_{n}
$$

defining $a_{i j}=\frac{x_{i j}}{X_{j}}, \quad i=1,2, \cdots, n$.

Table 1 can be explained following:

$$
\left\{\begin{array}{l}
a_{11} X_{1}+a_{12} X_{2}+\cdots+a_{1 n} X_{n}+y_{11}+y_{12}+\cdots+y_{1 n}=X_{1} \\
a_{21} X_{1}+a_{22} X_{2}+\cdots+a_{2 n} X_{n}+y_{21}+y_{22}+\cdots+y_{2 n}=X_{2} \\
\cdots \\
a_{n 1} X_{1}+a_{n 2} X_{2}+\cdots+a_{n n} X_{n}+y_{n 1}+y_{n 2}+\cdots+y_{n n}=X_{n}
\end{array}\right.
$$

thus

$$
\left[\begin{array}{cccc}
a_{11} & a_{12} & & a_{1 n} \\
a_{21} & a_{22} & \vdots & a_{2 n} \\
& \cdots & & \cdots \\
a_{n 1} & a_{n 2} & \vdots & a_{n n}
\end{array}\right] \times\left[\begin{array}{c}
X_{1} \\
X_{2} \\
\cdots \\
X_{n}
\end{array}\right]+\left[\begin{array}{c}
Y_{1} \\
Y_{2} \\
\cdots \\
Y_{n}
\end{array}\right]=\left[\begin{array}{c}
X_{1} \\
X_{2} \\
\cdots \\
X_{n}
\end{array}\right]
$$

\begin{tabular}{|c|c|c|c|c|c|c|c|c|c|c|}
\hline \multirow{2}{*}{ Input-output } & & \multicolumn{4}{|c|}{ Intermediate use } & \multicolumn{4}{|c|}{ Final use } & \multirow{2}{*}{ Total outpu } \\
\hline & & $\mathrm{C} 1$ & $\mathrm{C} 2$ & $\ldots$ & $\mathrm{Cn}$ & $\mathrm{C} 1$ & $\mathrm{C} 2$ & $\ldots$ & $\mathrm{Cn}$ & \\
\hline \multirow{4}{*}{ Intermediate use } & $\mathrm{C} 1$ & $x_{11}$ & $x_{12}$ & ... & $X_{1 n}$ & $y_{11}$ & $y_{12}$ & $\ldots$ & $y_{1 n}$ & $X_{1}$ \\
\hline & $\mathrm{C} 2$ & $x_{21}$ & $X_{22}$ & $\ldots$ & $x_{2 n}$ & $y_{21}$ & $y_{22}$ & $\ldots$ & $y_{2 n}$ & $X_{2}$ \\
\hline & $\ldots$ & $\ldots$ & $\ldots$ & $\ldots$ & $\ldots$ & $\ldots$ & $\ldots$ & $\ldots$ & $\ldots$ & $\ldots$ \\
\hline & $\mathrm{Cn}$ & $x_{n 1}$ & $x_{n 2}$ & $\ldots$ & $X_{n n}$ & $y_{n 1}$ & $y_{n 2}$ & $\ldots$ & $y_{n n}$ & $X_{n}$ \\
\hline Value added & & $V_{1}$ & $V_{2}$ & $\ldots$ & $V_{n}$ & & & & & \\
\hline Total output & & $X_{1}$ & $X_{2}$ & $\ldots$ & $X_{n}$ & & & & & \\
\hline
\end{tabular}

where $A=\left[\begin{array}{cccc}a_{11} & a_{12} & & a_{1 n} \\ a_{21} & a_{22} & \vdots & a_{2 n} \\ & \cdots & & \ldots \\ a_{n 1} & a_{n 2} & \vdots & a_{n n}\end{array}\right]$, naming “direct consumption coefficient matrix"

Table 1. Intra-national input-output table. 
Written in matrix:

$$
X_{n \times 1}=A_{n \times n} X_{n \times 1}+Y_{n \times 1}
$$

thus $X_{n \times 1}=\left(I-A_{n \times n}\right)^{-1} Y_{n \times 1}$, the matrix $(I-A)^{-1}$ is the "Leontief inverse" of the global input-output matrix.

Longitudinal view:

$$
x_{1 n}+x_{2 n}+\cdots+x_{n n}+V_{n}=X_{n}
$$

displayed in direct consumption coefficient matrix

$$
\left\{\begin{array}{l}
a_{11} X_{1}+a_{21} X_{1}+\cdots+a_{n 1} X_{1}+V_{1}=X_{1} \\
a_{12} X_{2}+a_{22} X_{2}+\cdots+a_{n 2} X_{2}+V_{2}=X_{2} \\
\cdots \\
a_{1 n} X_{n}+a_{2 n} X_{n}+\cdots+a_{n n} X_{n}+V_{n}=X_{n}
\end{array}\right.
$$

thus

$$
\sum_{i=1}^{n} a_{i j} X_{j}+V_{j}=X_{j}
$$

value added produced by country $j$ is $V_{j}=\left(1-\sum_{i=1}^{n} a_{i j}\right) X_{j}, \sum_{i=1}^{n} a_{i j}$ represents the proportion of the value produced by other countries on gross output; $1-\sum_{i=1}^{n} a_{i j}$ represents the proportion of value produced by country $j$.

Defining $a_{c j}=\sum_{i=1}^{n} a_{i j}$.

Diagonal matrix

$$
\hat{A}_{C}=\left[\begin{array}{cccc}
\sum_{i=1}^{n} a_{i 1} & & & \\
& & & \\
& \sum_{i=1}^{n} a_{i 2} & & \\
& & \ddots & \\
& & & \sum_{i=1}^{n} a_{i n}
\end{array}\right]=\left[\begin{array}{llll}
a_{c 1} & & & \\
& a_{c 2} & & \\
& & \ddots & \\
& & & a_{c n}
\end{array}\right]
$$

Value added matrix

$$
V=\left[\begin{array}{cccc}
1-a_{c 1} & & & \\
& 1-a_{c 2} & & \\
& & \ddots & \\
& & & 1-a_{c n}
\end{array}\right] \times\left[\begin{array}{c}
X_{1} \\
X_{2} \\
\vdots \\
X_{n}
\end{array}\right]=\left(I-\hat{A}_{c}\right) X
$$

If output is given, we can calculate value added.

\subsection{Value Added to Export Ratio (VAX Ratio)}

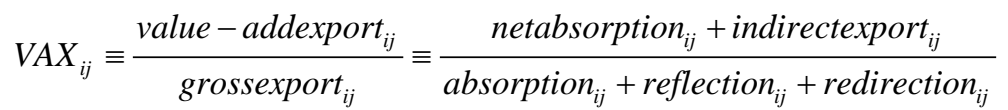


Equation (9) was based on two assumptions: firstly, the same proportion. In different sectors, the proportion of imported products used for domestic consumption and continued production is the same. In different countries, the proportion of imported products used for domestic consumption and continued production is the same. Secondly, the added value export must be fully absorbed by the trading partner countries, neither return to the country, nor re-exported to a third country.

According to Puzzello [14], the relaxation of the proportionality assumption does not have a significant impact on the results when all sectors in a country are taken as a whole; while the relaxation of ratio assumption is assumed to have a greater effect on the results at the bilateral level.

Due to the continuous development of fragmentation, there are plenty of carrying trade, that is to say, country B imports products from country A and then re-exports the processed goods to country C. Such exports may lead to VAX ratio greater than 1. However, the meaning of "value added exports" can be better explained by the domestic value added included in the final demand of foreign countries.

\subsection{Data}

In 2011, the WTO Director-General proposed to take value added as a multi-lateral foreign trade accounting standard. Governments and international organizations successively organized to develop database of input-output tables. At present, there are four databases widely used in the world and covering a wide range of areas.

The World Input-Output Database (WIOD) compiled by the European Union includes both versions 2013 and 2016. The 2013 version of the database covered input-output tables for 40 countries from 1995 to 2011, with 35 sectors in ISIC Rev.3; the 2016 version of the database covers input-output tables for 43 countries from 2000 to 2014, with the industrial sector increased from 35 in ISIC Rev. 3 to 56 in the ISIC Rev.4 standard. WIOD has most comprehensive coverage of countries and sectors in all value-added database.

On January 16, 2013, the OECD and the WTO jointly launched the Trade in Value Added Database (TiVA). The updated database covers 64 countries and regions in the world, 34 industries, from 1995 to 2011. The database is calculated according to WIOD input-output tables. All value added data in the paper come from TiVA.

In 1993, Purdue University started to implement the Global Trade Analysis Project (GTAP). The GTAP database is based on single-country non-competitive input-output tables. The database includes 66 economies and 55 sectors in 1979, 113 economies and 55 sectors in 2001 and 2004.

The Asian International Input-Output Table is the first systematic international input-output table compiled by the Institute of Developing Economies, covering 10 countries or regions, 75 industries in 1990, 1995 and 2000. In 2011, 
based on this database, Japan's IDE-JETRO and the WTO released the report titled "East Asian Trade Patterns and Global Value Chains: From Trade in Goods to Trade in Tasks", arousing the attention of scholars and the government (Table 2).

Value added and export data this paper are from TiVA database, which covers 64 economies and 34 industries. VAX ratio is calculated according to Equation (9).

\section{Trade Costs and Fragmentation}

\subsection{Processing Trade in China}

Figure 1 shows the relationship between VAX ratio and the distance. The Y1 axis is the average of VAX ratio of the remaining 62 economies from 1995 to 2011, and the Y2 axis is the geographical distance between China and these economies. As the distance increases, VAX ratio gradually increases. The higher VAX ratio means the smaller discrepancy between gross and value added trade flow, implying a decline trend in the fragmentation.

Table 2. Inter-country input-output database database widely used.

\begin{tabular}{ccccc}
\hline Database & WIOD (2016) & GTAP & TiVA & AIIOT \\
\hline Orgnization & EU & Purdue University & OECD \& WTO & IDE \\
Period & $1995-2011$ & 1979.2001 .2004 & $1995-2011$ & 1990.1995 .2000 \\
Country & 43 & 113 & 64 & 10 \\
Industry & 56 & 57 & 34 & 75 \\
\hline
\end{tabular}

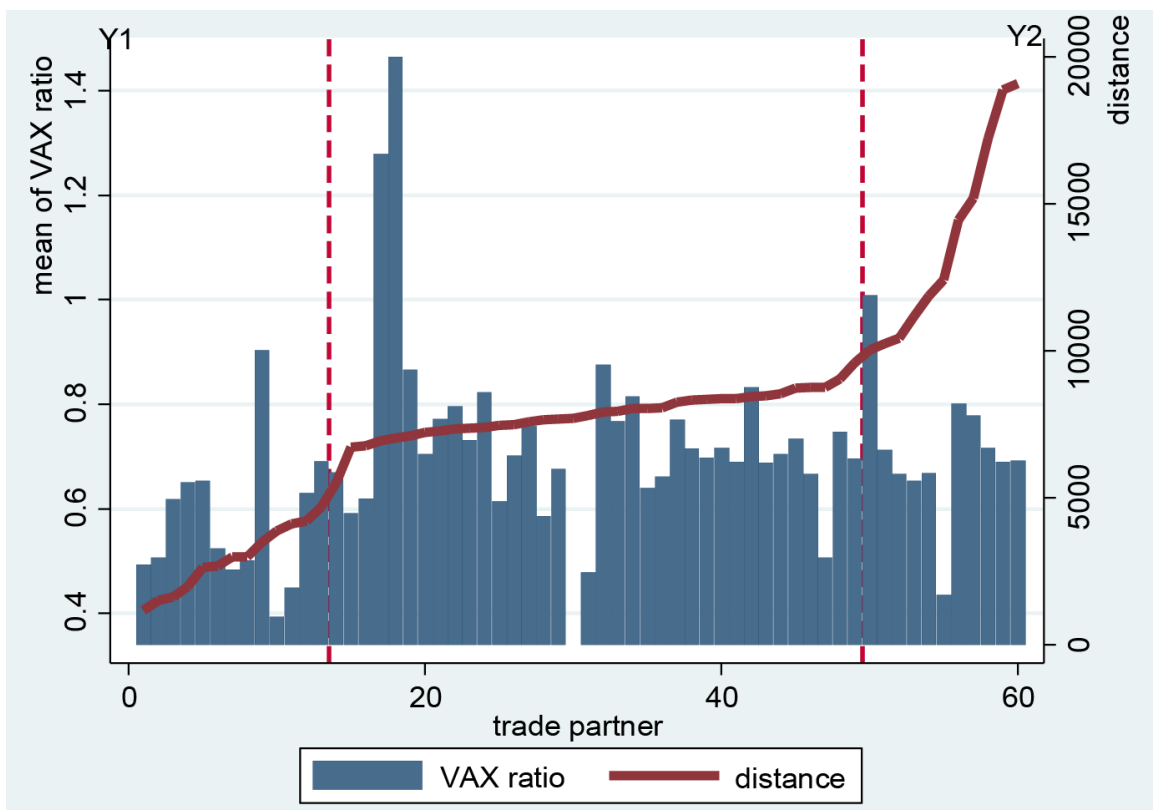

Figure 1. The relationship between VAX and distance; Note: data source from CEPII and TiVA database. 
Figure 1 is roughly divided into three regions: the leftmost region is Asian countries, VAX ratios are relatively small, mostly less than 0.6 ; the distance in the middle regions remains basically the same, while the VAX ratios are concentrated at 0.6 to 0.8 , slightly higher than the left area; in the rightmost area, the distance was significantly higher than the left and middle area, VAX ratios in the rightmost area are basically same as the middle, mainly for the Americas. Of course, the middle area contains the largest number of countries.

$\triangle \mathrm{VAX}$ ratio refers to the difference between the mean of VAX ratio in 2002-2011 and mean of VAX ratio in 1995-2000, that is, the change in VAX ratio before and after the accession to the WTO. In general, VAX ratio declined with time and the fragmentation production trend became more and more obvious. Figure 2 is also divided into three regions, with the leftmost region being Asian countries. About $85 \%$ (11/13) of them undertake declining trend in VAX ratio. The middle area is mainly European countries, 51\% (20/39) of which undergoing descending trend in processing trade. The rightmost area is American countries, 70\% (7/10) of which going through decreasing in processing trade. On the whole, processing trade is playing a significant role in China's foreign trade, especially trade with neighboring countries.

\subsection{Empirical Framework}

We have two goals: one is to explore how VAX ratios, gross trade, and value added trade respond to bilateral frictions, the other one is to make it clear how these responds have changed over time.

$$
\begin{aligned}
\log Y_{i j t} & =\alpha_{t}^{Y}+\beta_{1 t}^{Y} * \log d i s_{i j}+\beta_{2 t}^{Y} * \log g d p_{-} o+\beta_{3 t}^{Y} * g d p_{-} d \\
& +\beta_{4 t}^{Y} * \log p o p_{-} o+\beta_{5 t}^{Y} * \log p o p_{-} d+\beta_{6 t}^{Y} * \text { contig }_{i j} \\
& +\beta_{6 t}^{Y} * \text { comlang }_{i j}+\xi_{i j t}
\end{aligned}
$$

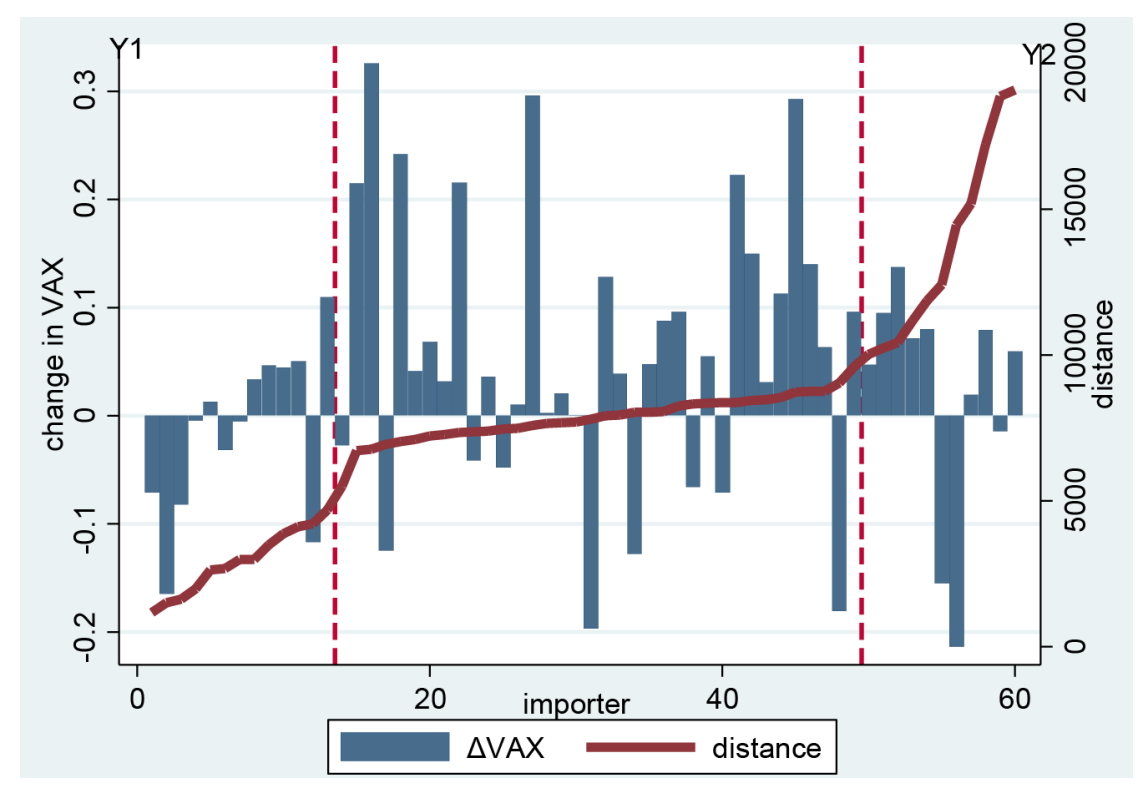

Figure 2. The relationship between $\triangle \mathrm{VAX}$ and distance. 
- $Y_{i j t}$ represents value added export or gross export;

- $i$ denotes exporting country, represent Chinese mainland in the paper; $j$ denotes 62 importing countries or regions;

- $d i s_{i j}$ denotes distance between importing countries and exporting countries

- $g d p_{-} o, g d p_{-} d$ denote GDP of exporting countries and importing countries respectively;

- $\quad p o p_{-} o, p o p_{-} d$ denote population in exporting countries and importing countries;

- contig is a virtual variable, the indicator takes the value one if the two countries share a land border;

- comlang is a virtual variable, the indicator takes the value one if the two countries share a common official language.

\subsection{OLS Regression Model}

Since the distance is a variable that does not change with time, the main explanatory variable "distance" will be omitted using the fixed effect model. However, the random model has no practical reference meaning. Hence OLS regression would be a better choice (Tables 3-5).

Table 3. Panel regression with $\log \mathrm{VAX}$ as explained variable.

\begin{tabular}{|c|c|c|c|c|c|c|}
\hline & (1) & (2) & (3) & (4) & (5) & (6) \\
\hline & $\log \mathrm{EX}$ & $\log \mathrm{EX}$ & $\log \mathrm{EX}$ & $\log \mathrm{EX}$ & $\log \mathrm{EX}$ & $\log \mathrm{EX}$ \\
\hline \multirow[t]{2}{*}{ logdis } & $-0.857^{\star * \star}$ & $-0.867^{\star * *}$ & $-0.683^{\star * *}$ & $-0.839^{* * *}$ & $-0.497^{\star * *}$ & $-0.596^{* * *}$ \\
\hline & $(-7.82)$ & $(-19.71)$ & $(-10.17)$ & $(-19.64)$ & $(-3.88)$ & $(-12.39)$ \\
\hline \multirow[t]{2}{*}{ loggdp_o } & & $0.999^{* * *}$ & & $0.221^{\star}$ & & $0.235^{\star \star}$ \\
\hline & & $(26.80)$ & & $(1.86)$ & & $(2.07)$ \\
\hline \multirow[t]{2}{*}{ loggdp_d } & & $0.946^{* * *}$ & & $0.862^{* * *}$ & & $0.839^{* * *}$ \\
\hline & & (61.48) & & (39.11) & & $(38.57)$ \\
\hline \multirow[t]{2}{*}{ logpop_o } & & & $31.33^{* * *}$ & $18.39^{* * *}$ & & $18.31^{\star * *}$ \\
\hline & & & $(26.26)$ & $(7.23)$ & & $(7.54)$ \\
\hline \multirow[t]{2}{*}{ logpop_d } & & & $0.749^{* * *}$ & $0.114^{* * *}$ & & $0.138^{\star * *}$ \\
\hline & & & $(32.14)$ & $(5.21)$ & & $(6.11)$ \\
\hline \multirow[t]{2}{*}{ contig } & & & & & $0.919^{\star * *}$ & 0.151 \\
\hline & & & & & $(3.33)$ & $(1.37)$ \\
\hline \multirow[t]{2}{*}{ comlang_off } & & & & & $1.140^{* * *}$ & $1.100^{* * *}$ \\
\hline & & & & & (3.92) & (9.94) \\
\hline \multirow[t]{2}{*}{ _cons } & $14.99^{* * *}$ & $2.726^{* * *}$ & $-212.8^{\star * *}$ & $-123.1^{* * *}$ & $11.67^{* * *}$ & $-124.9^{* * *}$ \\
\hline & (15.44) & $(5.70)$ & $(-24.86)$ & $(-7.09)$ & $(10.16)$ & $(-7.54)$ \\
\hline $\mathrm{N}$ & 1054 & 1054 & 1054 & 1054 & 1054 & 1054 \\
\hline
\end{tabular}

Note: ${ }^{*} \mathrm{p}<0.1,{ }^{* *} \mathrm{p}<0.05,{ }^{* * *} \mathrm{p}<0.01$. 
Table 4. Panel regression with $\log \mathrm{VA}$ as explained variable.

\begin{tabular}{|c|c|c|c|c|c|c|}
\hline & (1) & (2) & (3) & (4) & (5) & (6) \\
\hline & $\log V A$ & $\log V A$ & $\log V A$ & $\operatorname{logVA}$ & $\log \mathrm{VA}$ & $\log \mathrm{VA}$ \\
\hline \multirow[t]{2}{*}{ logdis } & $-0.739^{\star * *}$ & $-0.749^{* * *}$ & $-0.570^{* * *}$ & $-0.725^{\star * *}$ & $-0.419^{\star * *}$ & $-0.521^{\star * *}$ \\
\hline & $(-7.05)$ & $(-20.36)$ & $(-8.99)$ & $(-20.09)$ & $(-3.41)$ & $(-12.76)$ \\
\hline \multirow[t]{2}{*}{ loggdp_o } & & $0.964^{\star * *}$ & & $0.480^{\star * *}$ & & $0.487^{\star * *}$ \\
\hline & & $(30.92)$ & & $(4.78)$ & & $(5.06)$ \\
\hline \multirow[t]{2}{*}{ loggdp_d } & & $0.929^{* * *}$ & & $0.856^{* * *}$ & & $0.845^{\star * *}$ \\
\hline & & $(72.25)$ & & $(46.00)$ & & $(45.73)$ \\
\hline \multirow[t]{2}{*}{ logpop_o } & & & $29.86^{* * *}$ & $11.65^{* * *}$ & & $11.62^{* * *}$ \\
\hline & & & $(26.54)$ & $(5.43)$ & & $(5.64)$ \\
\hline \multirow[t]{2}{*}{ logpop_d } & & & $0.730^{* * *}$ & $0.0997^{* * *}$ & & $0.108^{* * *}$ \\
\hline & & & $(33.22)$ & (5.39) & & $(5.61)$ \\
\hline \multirow[t]{2}{*}{ contig } & & & & & $0.970^{* * *}$ & $0.264^{\star * *}$ \\
\hline & & & & & $(3.67)$ & $(2.82)$ \\
\hline \multirow[t]{2}{*}{ comlang_off } & & & & & $0.895^{\star * *}$ & $0.830^{\star * *}$ \\
\hline & & & & & $(3.21)$ & $(8.84)$ \\
\hline \multirow[t]{2}{*}{ _cons } & $13.56^{* * *}$ & $1.646^{* * *}$ & $-203.6^{* * *}$ & $-78.18^{\star * *}$ & $10.61^{* * *}$ & $-79.83^{* * *}$ \\
\hline & (14.59) & $(4.12)$ & $(-25.23)$ & $(-5.34)$ & (9.63) & $(-5.68)$ \\
\hline $\mathrm{N}$ & 1054 & 1054 & 1054 & 1054 & 1054 & 1054 \\
\hline
\end{tabular}

Note: ${ }^{*} \mathrm{p}<0.1,{ }^{* *} \mathrm{p}<0.05,{ }^{* * *} \mathrm{p}<0.01$.

Table 5. Panel regression with $\log \mathrm{VAX}$ as explained variable.

\begin{tabular}{|c|c|c|c|c|c|c|}
\hline & (1) & (2) & (3) & (4) & (5) & (6) \\
\hline & $\operatorname{logVAX}$ & $\log V A X$ & $\log \mathrm{VAX}$ & $\log V A X$ & $\operatorname{logVAX}$ & $\log \mathrm{VAX}$ \\
\hline \multirow[t]{2}{*}{ logdis } & $0.118^{\star * *}$ & $0.118^{* * *}$ & $0.113^{* * *}$ & $0.115^{* * *}$ & $0.0777^{* * *}$ & $0.0749^{* * *}$ \\
\hline & $(8.30)$ & $(8.40)$ & $(8.15)$ & $(8.37)$ & $(4.71)$ & $(4.77)$ \\
\hline \multirow[t]{2}{*}{ loggdp_o } & & $-0.0351^{\star * *}$ & & $0.259^{* * *}$ & & $0.252^{\star * *}$ \\
\hline & & $(-2.95)$ & & $(6.80)$ & & $(6.80)$ \\
\hline \multirow[t]{2}{*}{ loggdp_d } & & $-0.0164^{\star * *}$ & & -0.00616 & & 0.00549 \\
\hline & & $(-3.33)$ & & $(-0.87)$ & & $(0.77)$ \\
\hline \multirow[t]{2}{*}{ logpop_o } & & & $-1.470^{* * *}$ & $-6.736^{* * *}$ & & $-6.696^{\star * *}$ \\
\hline & & & $(-5.95)$ & $(-8.27)$ & & $(-8.45)$ \\
\hline \multirow[t]{2}{*}{ logpop_d } & & & $-0.0189^{* * *}$ & $-0.0144^{\star *}$ & & $-0.0305^{\star * \star}$ \\
\hline & & & $(-3.91)$ & $(-2.05)$ & & $(-4.13)$ \\
\hline \multirow[t]{2}{*}{ contig } & & & & & 0.0513 & $0.112^{* * *}$ \\
\hline & & & & & $(1.45)$ & $(3.12)$ \\
\hline \multirow[t]{2}{*}{ comlang } & & & & & $-0.245^{\star * *}$ & $-0.270^{\star * *}$ \\
\hline & & & & & $(-6.55)$ & $(-7.47)$ \\
\hline \multirow[t]{2}{*}{ _cons } & $-1.427^{\star * *}$ & $-1.080^{* * *}$ & $9.182^{* * *}$ & $44.92^{* * *}$ & $-1.060^{* * *}$ & $45.03^{* * *}$ \\
\hline & $(-11.34)$ & $(-7.08)$ & $(5.18)$ & $(8.08)$ & $(-7.17)$ & $(8.32)$ \\
\hline $\mathrm{N}$ & 1054 & 1054 & 1054 & 1054 & 1054 & 1054 \\
\hline
\end{tabular}

Note: ${ }^{*} \mathrm{p}<0.1,{ }^{* *} \mathrm{p}<0.05,{ }^{* * *} \mathrm{p}<0.01$. 
The correlation of $\log E X$ and distance is negative, so does the correlation of $\log V A$ and distance, implying that distance depresses both gross and value added trade. To some extent, distance represents trade cost, the longer the distance between the two countries, the higher the trade cost and the smaller flow of bilateral trade. This conclusion is consistent with most scholars' conclusions. In addition, the absolute value of distance coefficient on gross trade is larger than the coefficient on value added trade, indicating that the distance has different effects on the total exports and the value-added exports.

\subsection{Varying-Coefficient Regression Model}

Distance does not change over time, however, the trade volume between the two countries will change with the external political and economic environment changing, thus the impacts of distance on gross export, value added export change over time. It is reasonable to assume the coefficient is time variable.

According to Figure 3, absolute value of $\beta_{1 t}^{E X}, \beta_{1 t}^{V A}$ decrease with time, meaning the negative effect of distance on bilateral trade flows is getting smaller and smaller. This can also be explained from the perspective of technological development. With development of science and technology, transport costs are getting lower and lower, thus the trade costs caused by distance are getting smaller and smaller. Therefore, the impact of distance on bilateral trade is getting smaller and smaller. The conclusion here is inconsistent with that of Robert Johnson (2012a). Johnson took 42 countries (mainly EU-developed countries) as observations, and came to the conclusion that the negative correlation between distance and value-added exports and gross exports is more and more obvious. The coefficient is negative, but its absolute value is increasing. One possible reason is that whether the country exports or not depends on its trade costs and

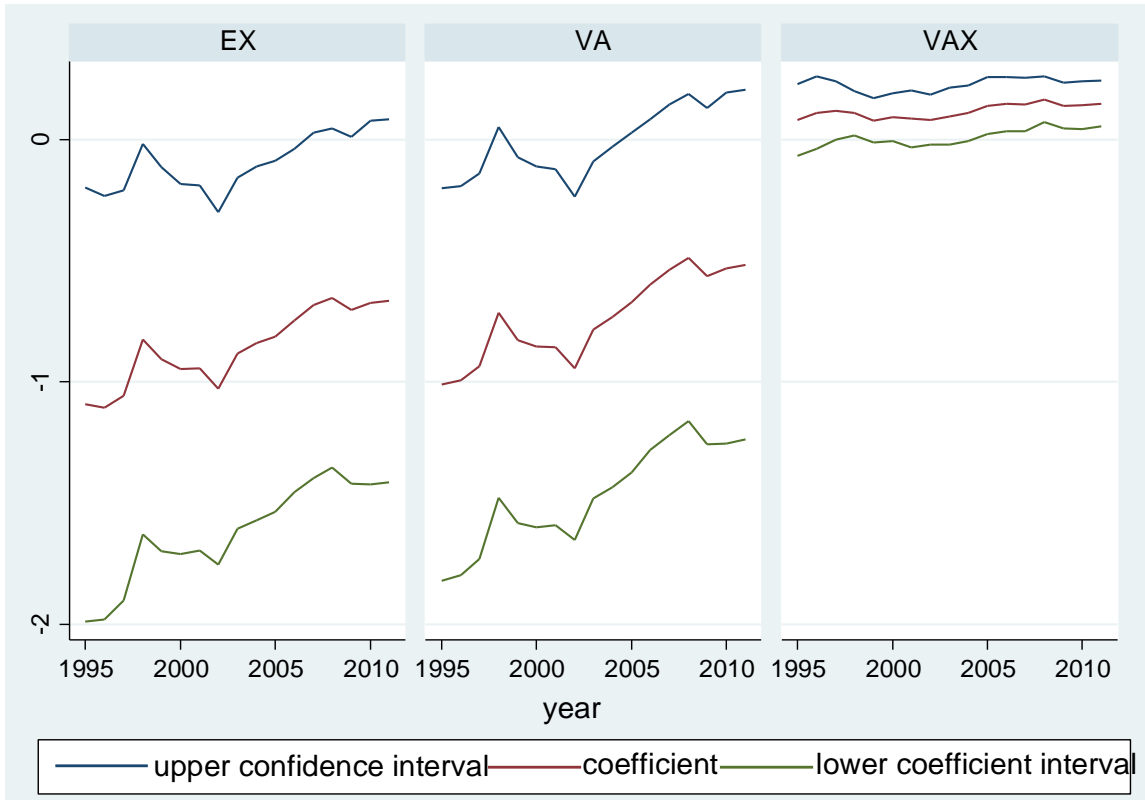

Figure 3. Results of varying coefficient regression. 
trade receipts. Taking China for example, with low labor cost and sluggish domestic demand, China provides cheap products for the world to increase income. With decreasing trade cost and China's strong export demand, the "restraining" effect on exports is weakening. In addition, the absolute value of the EX regression coefficient is always greater than the absolute value of the VA regression coefficient.

The coefficient of VAX ratio and distance is positive, that is, the farther the distance between the two economies, the greater the VAX ratio, the more frequently processing trade between the two economies. With the passage of time, the coefficient shows an increasing tendency. Before 2003, the coefficient was generally less than 0.1. After 2005, the coefficient value was above 0.14. In 1995, the coefficient was 0.08 , meaning that for every $1 \%$ increase in distance, the VAX ratio increases by 0.08 percentage, while the proportion of processing trade on gross trade decreases by 0.08 percentage points. In 2010, the coefficient was 0.142 , meaning that for 1 percentage increase in distance, 0.142 increase in VAX ratio, the proportion of processing trade decreased 0.142 percentage drop out. That is the so-called fragmentation.

\subsection{Robust Test}

In order to test the relationship between the main explanatory variables and processing trade, the proportion of trade in intermediate products on gross trade replace the VAX ratio to measure the extent of processing trade cooperation. The higher proportion of processing trade, the great extent of product cooperation. According to the previous analysis, the closer countries are, the more intensive the processing trade cooperation is. The further countries are, the lower degree of cooperation in processing trade is, that is, the coefficient of the ratio on distance should be negative (Table 6).

\section{Conclusions}

Based on a new accounting method for international trade-Trade in Value Added Accounting System, a new indicator VAX ratio, can be defined to measure fragmentation. The discrepancy between gross and value added trade flow is precisely due to the double counting of intermediate products. The lower the VAX ratio, the greater the fragmentation. According to the analysis of China and its trade with 62 major economies, the paper came to two conclusions: 1) Distance has a "restraining" effect on processing trade. The closer the two countries are, the more frequently processing trade occurs. 2) Relative productivity of the two countries, and economic scale do not affect processing trade significantly.

Processing trade has always been the main force of China's foreign trade. In recent years, with the weakening of the world economy, the growth momentum of processing trade has weakened, and the government has introduced a series of measures to improve the processing trade. "One Belt and One Road" strategy 
Table 6. Panel regression with the proportion of intermediate trade as explained variable.

\begin{tabular}{|c|c|c|c|c|c|c|}
\hline & (1) & (2) & (3) & (4) & (5) & (6) \\
\hline & $\log I N T$ & $\log I N T$ & $\operatorname{logINT}$ & $\log I N T$ & $\log I N T$ & $\operatorname{logINT}$ \\
\hline \multirow[t]{2}{*}{ logdis } & $-0.141^{\star \star \star}$ & $-0.141^{\star * *}$ & $-0.139^{\star * *}$ & $-0.137^{\star * *}$ & $-0.157^{\star * *}$ & $-0.153^{\star * *}$ \\
\hline & $(-10.53)$ & $(-10.55)$ & $(-10.38)$ & $(-10.22)$ & $(-9.97)$ & $(-9.76)$ \\
\hline \multirow[t]{2}{*}{ loggdp_o } & & $0.0224^{* *}$ & & 0.0298 & & 0.0335 \\
\hline & & (1.99) & & $(0.80)$ & & $(0.90)$ \\
\hline \multirow[t]{2}{*}{ loggdp_d } & & 0.00263 & & -0.00836 & & $-0.0145^{\star *}$ \\
\hline & & $(0.56)$ & & $(-1.21)$ & & $(-2.04)$ \\
\hline \multirow[t]{2}{*}{ logpop_o } & & & $0.477^{\star *}$ & -0.0542 & & -0.0766 \\
\hline & & & $(2.01)$ & $(-0.07)$ & & $(-0.10)$ \\
\hline \multirow[t]{2}{*}{ logpop_d } & & & $0.00863^{\star}$ & $0.0148^{\star *}$ & & $0.0251^{* * *}$ \\
\hline & & & $(1.86)$ & $(2.15)$ & & (3.39) \\
\hline \multirow[t]{2}{*}{ contig } & & & & & $-0.100^{* * *}$ & $-0.145^{\star * *}$ \\
\hline & & & & & $(-2.96)$ & $(-4.02)$ \\
\hline \multirow[t]{2}{*}{ comlang } & & & & & -0.00768 & 0.0145 \\
\hline & & & & & $(-0.21)$ & $(0.40)$ \\
\hline \multirow[t]{2}{*}{ _cons } & $0.562^{\star * *}$ & $0.379^{* * *}$ & $-2.895^{\star}$ & 0.695 & $0.716^{* * *}$ & 0.985 \\
\hline & $(4.75)$ & $(2.62)$ & $(-1.70)$ & $(0.13)$ & $(5.06)$ & $(0.18)$ \\
\hline $\mathrm{N}$ & 1054 & 1054 & 1054 & 1054 & 1054 & 1054 \\
\hline
\end{tabular}

Note: ${ }^{*} \mathrm{p}<0.1,{ }^{* *} \mathrm{p}<0.05,{ }^{* *} \mathrm{p}<0.01$.

helps construct infrastructure in neighboring countries aiming at strengthening China's contact with countries along the Belt and Road, thus promoting the processing trade between China and the countries. Due to the regionalization of production, the processing trade in China and the surrounding areas will gradually become the main force of China's external processing trade. Therefore, infrastructure construction in countries along the Belt and Road will play an important role in promoting intra-Asia processing trade.

\section{References}

[1] Carrère, C. and Schiff, M. (2005) On the Geography of Trade: Distance Is Alive and Well. Revue Economique, 56, 1249-1274. https://doi.org/10.3917/reco.566.1249

[2] Wan, L.L. and Gao, X. (2014) The Influence of the Distance of Culture, Geography and institution on China's Import and Export Trade-Experience Data of Import and Export Trade from 32 Countries and Regions. International Economics and Trade Research, 30, 39-48.

[3] Ellis, P.D. (2007) Paths to Foreign Markets: Does Distance to Market Affect Firm Internationalisation? International Business Review, 16, 573-593. https://doi.org/10.1016/j.ibusrev.2007.06.001

[4] Meyer, K.E., Estrin, S., Bhaumik, S.K., et al. (2009) Institutions, Resources, and Entry Strategies in Emerging Economies. Strategic Management Journal, 30, 61-80. 
https://doi.org/10.1002/smj.720

[5] Yi, K.M. (2008) Can Multistage Production Explain the Home Bias in Trade? American Economic Review, 100, 364-393. https://doi.org/10.1257/aer.100.1.364

[6] Balassa, B. (1965) Trade Liberalisation and "Revealed" Comparative Advantage. The Manchester School, 33, 99-123. https://doi.org/10.1111/j.1467-9957.1965.tb00050.x

[7] Hummels, D., Ishii, J. and Yi, K.M. (2001) The Nature and Growth of Vertical Specialization in World Trade. Journal of International Economics, 54, 75-96. https://doi.org/10.1016/S0022-1996(00)00093-3

[8] Robert, K., William, P., Wang, Z. and Wei, S.-J. (2010) Give Credit Where Credit Is Due: Tracing Value Added in Global Production Chains. NBER Working Paper 16426.

[9] Koopman, R. and Wang, Z. (2012) Tracing Value-Added and Double Counting in Gross Exports. Social Science Electronic Publishing, 104, 459-494. https://doi.org/10.3386/w18579

[10] Wang, Z., Wei, S.-J. and Zhu, K.-F. (2015) Total Trade Accounting: Official Trade Statistics and the Measurement of Global Value Chains. Social Sciences in China, 9, 108-127.

[11] Johnson, R.C. and Noguera, G. (2012) Fragmentation and Trade in Value Added Over Four Decades. National Bureau of Economic Research, Inc, NBER Working Paper 18186. https://doi.org/10.3386/w18186

[12] Johnson, R.C. and Noguera, G. (2012) Proximity and Production Fragmentation. American Economic Review, 102, 407-411. https://doi.org/10.1257/aer.102.3.407

[13] Ma, H., Wang, Z. and Zhu, K.F. (2015) Domestic Content in China's Exports and Its Distribution by Firm Ownership. Journal of Comparative Economics, 43, 3-18. https://doi.org/10.1016/j.jce.2014.11.006

[14] Puzzello, L. (2012) A Proportionality Assumption and Measurement Biases in the Factor Content of Trade. Journal of International Economics, 87, 105-111.

https://doi.org/10.1016/j.jinteco.2011.11.009 